\title{
MOLECULAR AND BIOLOGICAL CHARACTERISTICS, AND CULTIVATION OF AN ATTENUATED STRAIN 1974-VNIIVViM OF RIFT VALLEY FEVER VIRUS
}

\section{I.R. IMATDINOV, V.I. BALYSHEVA, V.N. PONOMAREV, O.V. KAPUSTINA}

\begin{abstract}
All-Russian Institute of Veterinary Virology and Microbiology, Federal Agency of Scientific Organizations, Pokrov, Petushinskii Region, Vladimir Province, 601120 Russia, e-mail VNIIVViM@niiv.petush.elcom.ru, ilnazicf@ya.ru,balyvi@uandex.ru
\end{abstract}

Received July 27, 2015

\section{Abstract}

In recent decades, a threat of spreading Rift Valley fever (RVF) to Asia and Europe raises serious concerns. Within many years, vaccines against RVF were developed in several ways including designing attenuated vaccine versions, inactivated or genetically engineered vaccines. A serious hazard of the RVF agent requires developing sufficiently immunogenic preparations providing both RVF specific prevention and safety precautions in production procedures. Therefore, this work was aimed at molecular and biological characterization of an attenuated RVF virus (RVFV) strain 1974VNIIVViM including search for high-tech cell culture systems for the virus growth and determination of its antigenic and/or immunogenic relationship with a virulent strain Entebbe. The results of the investigations showed that the virus accumulated in continuous cell cultures like saiga kidney (SK), Siberian mountain goat kidney (PSGK-60) and MDVK (calve kidney cell culture) at high titers with infectious $\left(8.53 \pm 0.21 \mathrm{lg} \mathrm{MICLD}_{50} / \mathrm{cm}^{3}\right)$ and antigenic $(1: 64$ to $1: 128$ in the passive hemagglutination test, PHT) activity levels. We determined optimal regime of the virus growth in BHK-21/13 (Syrian hamster kidney cell culture) using a roller culture method: the culture bottle rotation speed of 12 to 15 r.p.h.; the infection dosage of 0.01 to $0.001 \mathrm{MLD}_{50} /$ cell; the first 12 hours of the culture at $\mathrm{pH}=6.4$ to 6.8 . Further, $\mathrm{pH}$ is maintained at 7.2 to 7.6 for 48 to 72 hours of culture at $37{ }^{\circ} \mathrm{C}$, which provides the raw virus production at high infectivity (8.5 to $8.9 \pm 0.2 \mathrm{lg}$ MICLD $_{50} / \mathrm{cm}^{3}$ ) and antigenicity (1:128 to $1: 256$ in PHT and $1: 625$ to $1: 3125$ in solid phase ELISA) levels. Phylogenetic analysis of the nucleotide sequences of 3 sites in $\mathrm{S}$ and/or $\mathrm{M}$ segments showed that it was closely related to strains Smithburn and Entebbe allowing their grouping into a separate cluster. Comparative analysis of nucleotide sequences of genes encoding glycoproteins $\mathrm{Gn}$ and $\mathrm{Gc}$, and the nucleoprotein N, shows that most of the substitutions in the sequences of the genes of the RVFV strain 1974-VNIIVViM are synonymous and do not alter the primary amino acid sequence, with insertion and deletion missing. In the nucleotide sequence encoding glycoprotein $\mathrm{Gn}$ of strain 1974-VNIIVViM we found 8 substitutions relative to a similar sequence of $\mathrm{M}$ segment of a virulent strain Entebbe, and 14 substitutions when compared with M segment of strain Smithburn. A lower (as compared with other attenuated strains) amount of significant amino acid substitutions in RVFV antigenic components was revealed; thus, strain 1974-VNIIVViM selection as a source of immunodominant proteins and/or raw virus for vaccine production seems to be well-grounded.

Keywords: Rift Valley fever, viral culture, antigenicity, immunogenicity, electron microscopy, phylogenetic analysis.

Rift Valley fever (RVF) is a transmissible acute zooanthroponosis with the symptoms of intoxication, fever, necrotizing hepatitis, hemorrhagic gastroenteritis with high mortality in lambs and goatlings. The causal pathogenic agent RVF virus (Rift Valley fever virus - RVFV) belongs to family Bunyaviridae, genus Phlebovirus. Currently, RVF attracts close attention of researchers, as it is considered a highly dangerous zooantroponosis causing great economic losses which is made up of the losses from abortion, high percentage of mortality in young animals, a sharp decline in the productivity of livestock, and the cost of quarantine and preventive measures, as well as of hospitalization and treatment of humans [1].

Manifestation of this disease in the form of epizootic outbreaks is ob- 
served in the African and Asian countries. However, according to research performed by the Wildlife Conservation Society, global warming would cause changes in the ecosystems characteristic to certain climatic zones. In particular, the warming may result in the spreading and an increased number of potential RVF pathogen transmitters, the Culex tritaeniorhynchus and Aedes vexans arabiensis. All this indicates a threat of spreading Rift Valley fever over the countries that have so far been free of the disease [2-4]. In recent decades, a threat of RVF spreading to Asia and Europe raises serious concerns [5-7].

Within many years, vaccines against RVF have been developed in several ways including designing attenuated vaccine versions [8-11], inactivated whole virus and subunit vaccines [12-14], viral vector-based vaccines, and DNA vaccines [15-22]. In Russia, Rift Valley fever is studied among the other highly dangerous animal and human infections, and particularly, diagnostic methods and the means of specific prevention and control measures are being developed [23]. An attenuated strain 1974-VNIIVViM of RVF virus has been designed in the All-Russian Research Institute of Veterinary Virology and Microbiology using serial passage technique in suckling mice. A domestic test system for the detection of this virus by RT-PCR and immunoassay has been suggested [24, 25].

To date, live vaccines against RVF produced of the attenuated strain are used in veterinary practice in endemic area. However, these may cause abortion or have teratogenic effects on the fetus due to residual virulence of Smithburn strain. At the same time, according to the researchers' reports, new attenuated candidate vaccines (MP-12, Clone 13, etc.) may have the same disadvantages [5, 11]. An inactivated vaccine has been developed for humanitarian medicine; it is used for experimental purposes but has not been registered and is not commercially available [14].

Production of live and inactivated vaccines is knows to require a large amount of raw virus of high infectious and immunogenic activity. In this study, we first showed that high titers of RVF strain 1974-VNIIVViM are accumulated is the saiga kidney, green monkey kidney, and Syrian hamster kidney continuous cell cultures, and have high infectious and antigenic activity. The identified high closeness of strain 1974-VNIIVViM to known strains Smithburn and Entebbe, as well as the low number of significant amino acid substitutions in its antigenic components point to the possibility of using strain 1974-VNIIVViM as a source of immunodominant protein genes and as raw virus for the vaccine production.

This research was aimed at the search for high-tech cell culture systems for the reproduction of attenuated strain 1974-VNIIVViM of Rift Valley fever virus and the study of its molecular and biological properties including identification of antigenic and immunogenic closeness to the reference virulent (Entebbe) and attenuated (Smithburn) strains.

Technique. Attenuated strain 1974-VNIIVViM with infectious activity of 6.0-6.5 $\mathrm{lg} \mathrm{TCD}_{50} / \mathrm{cm}^{3}$ (50\% tissue cytopathic dose) was obtained from the AllRussian Scientific Research Institute of Veterinary Virology and Microbiology (VNIIVViM) collection of microorganisms. Continuous cell cultures, such as Syrian hamster kidney (BHK-21/13), calve kidney (MDVK), saiga kidney (SK), green monkey (CV-1), Siberian mountain goat kidney (PSGK-60), African goat embryo (PEAK), and primary lamb kidney (LC) cell cultures were used to compare the effectiveness of RVF virus accumulation in continuous and primary cell cultures. All cell cultures were obtained from the VNIIVViM cell strain museum. Eagle MEM culture medium (Minimum Essential Medium Eagle, Sigma, USA) and $0.25 \% \mathrm{MEH}$ suspension (muscle enzymatic hydrolyzate) medium (VNIIVViM) enriched in B-vitamins and L-glutamine $\left(600 \mathrm{mg} / \mathrm{dm}^{3}\right)$, and supplemented with 5-10\% cattle blood serum (Biolot, Russia) were used for cell culture. The growth medium was removed from culture flasks (1.5 liter volume) with grown 
monolayer, then the maintenance medium supplemented with $2 \%$ serum was added. Multiplicity of infection was $0.01 \mathrm{TCD}_{50} /$ cell. The infected culture was incubated until 80-100\% CPE (cytopathic effect). Three to five consecutive passages were performed for each cell culture.

Virus was propagated at $37^{\circ} \mathrm{C}$ for 3-4 days statically, in roller and suspension cultures depending on cell substrate, multiplicity of infection and culture regime. Commercial shelf rack roller systems (NBS, USA), the systems designed and manufactured in VNIIVViM for industrial cell and virus culture (applicable to monolayer and suspension culture), and laboratory fermenters (NBS, USA; Biostat, Germany; Chemap, Switzerland) were used.

Viral infectious activity was estimated by conventional techniques, i.e. titration in CV-1, SK or PSGK cell cultures in 96-well plates or in 1-3-day-old white mice of 18-20 g weight at intracerebral infection. Viral titers were calculated according to Reed and Mench as modified according to Ashmarin and expressed as $\lg \mathrm{TCD}_{50} / \mathrm{cm}^{3}$ or $\lg \mathrm{MLD}_{50} / \mathrm{cm}^{3}$ (50\% murine lethal dose) [26]. Antigenic activity of virus-containing material was tested in the reaction of passive haemagglutination (PHA) and the «sandwich» solid phase enzyme linked immunosorbent assay (ELISA-SP), using erythrocytic diagnosticum and the «Diagnostic products for ELISA-SP with RVF» kit (VNIIVViM), respectively.

In molecular studies, we used the earlier developed plasmid library of full length genes encoding immunodominant viral proteins of strain 1974-VNIIVViM [27], the nucleotide sequences of corresponding plasmids deposited by us in the GenBank (KF876008 and KF876009 for Gn and Gc glycoproteins, and KF876010 for $\mathrm{N}$ nucleoprotein), and other nucleotide sequences, which have been identified to date in the virulent and attenuated strains and isolates of RVF virus, i.e. Entebbe (GenBank DQ380156.1), Smithburn (GenBank DQ380157.1), ZH548 (GenBank DQ380151.1), MP-12 (GenBank DQ380154.1), Kenya 9800523 (GenBank DQ380169.1). Evolutionary and phylogenetic analysis was performed with MEGA v. 6.06 software (http://www.megasoftware.net/mega.php) according to the maximum likelihood method based on the $\mathrm{K}$. Tamura and M. Nei [28] model. Initial dendrograms for subsequent heuristic search were obtained using Neighbor-Join and BioNJ algorithms.

For electron microscopy with ultrathin section negative contrasting [29] a JEM-100S Electron Microscope (Jeol, Japan) was applied.

Statistical analysis was performed according to G.F. Lakin [30] using R 3.1.1 and Microsoft Office Excel 2013 software.

Results. The dependence of strain 1974-VNIIVViM accumulation on multiplicity of infection (in the range of 0.01 to $0.000001 \mathrm{TCD}_{50} /$ cell), cattle serum concentration in the maintenance medium $(0 \%, 2 \%$, and $5 \%), \mathrm{pH}$ (6.4-7.6 in increments of 0.2), and time of stationary cultivation was studied in monolayer cell cultures of all the used lines. Along with LK cells, SK, CV-1, and BHK-21/13 lines produced high virus titers, whereas in PEAK, MDVK, and PSGK-60 cell cultures the virus titers were lower by 0.4-0.9 lg $\mathrm{TCD}_{50} / \mathrm{cm}^{3}$ (Table).

For continuous SK, CV-1, BHK-21/13 cell cultures, the high titer virus production was shown with infectious activity of $8.53 \pm 0.21 \mathrm{lg} \mathrm{MLD}_{50} / \mathrm{cm}^{3}$ and 6.50-6.90 $\mathrm{lg} \mathrm{TCD}_{50} / \mathrm{cm}^{3}$, and antigenic activity of $1: 64$ to $1: 128$ in PHT. In SK cell culture under the roller method (with bottle volume of $3 \mathrm{dm}^{3}, 12$ to 15 r.p.h. rotation, temperature of $37{ }^{\circ} \mathrm{C}$, infection dosage of 0.01 to 0.001 $\mathrm{MLD}_{50}$ /cell, $\mathrm{pH} 6.4$ to 6.8 for the first 12 hours and than from 7.2 to 7.6 for 48 to 72 hours), the high raw virus infectivity (8.5 to $8.9 \pm 0.2 \mathrm{lg} \mathrm{MLD}_{50} / \mathrm{cm}^{3}$ ) and antigenicity (1:128 to $1: 256$ in PHT and $1: 625$ to $1: 3125$ in solid phase ELISA) were provided (Fig. 1). 
Sensitivity of cell cultures to Rift Valley fever virus strain 1974-VNIIVViM depending on passage number under stationary conditions

\begin{tabular}{c|l|c|c}
\hline Number of passages & Cell culture & $\begin{array}{c}\text { Time of 80-100\% } \\
\text { CPE development }\end{array}$ & $\begin{array}{c}\text { Infectious activity } \\
\text { titer TCD }\end{array} \mathrm{cm}^{3}(X \pm X)$ \\
\hline 7 & BHK-21/13 & $3-4$ & $6.50 \pm 0.15$ \\
9 & SK & 4 & $6.90 \pm 0.14$ \\
5 & CV-1 & $3-4$ & $6.50 \pm 0.25$ \\
4 & PSGK-60 & $3-4$ & $6.22 \pm 0.17$ \\
5 & LK & 3 & $6.32 \pm 0.14$ \\
5 & PEAK & $3-4$ & $5.70 \pm 0.21$ \\
5 & MDVK & $3-5$ & $6.00 \pm 0.25$
\end{tabular}

N o t e. Continuous (BHK-21/13, SK, CV-1, PSGK-60, PEAK, MDVK) and primary (LK) kidney cell cultures of Syrian hamster, saiga, green monkey, Siberian mountain goat, African goat embryo, calf and lamb (obtained from the Museum of cell strains of the All-Russian Research Institute of Veterinary Virology and Microbiology).
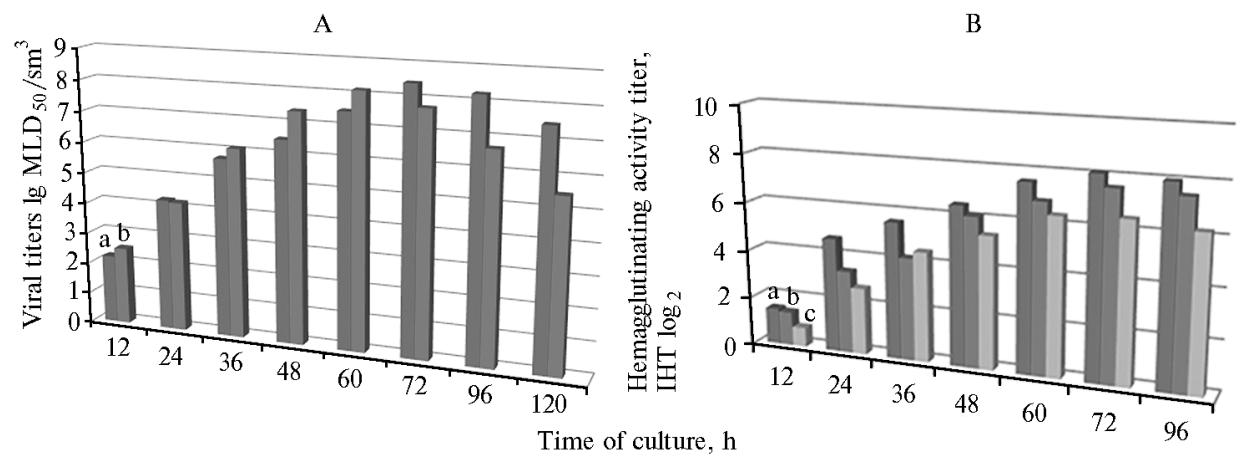

Fig. 1. Dynamics of infectious and antigenic activity of Rift Valley fever virus strain 1974VNIIVViM under propagation in saiga (SK) (A) and Syrian hamster (BHK-21/13) (B) kidney cell cultures using roller (a), stationary (b) and suspension (c) methods. MLD - murine lethal dose. The results of infectious activity estimation were obtained by titration, antigenic activity was assessed by passive hemagglutination.

Infectious and hemagglutinating viral activity in SK cell culture was found to be significantly higher compared to other cell cultures at day 4 . Hemagglutinating activity titer in a circular monolayer reached 1:512 in PHT.

Thus, the roller culture method provided maximum viral antigenic activity (see Fig. 1).

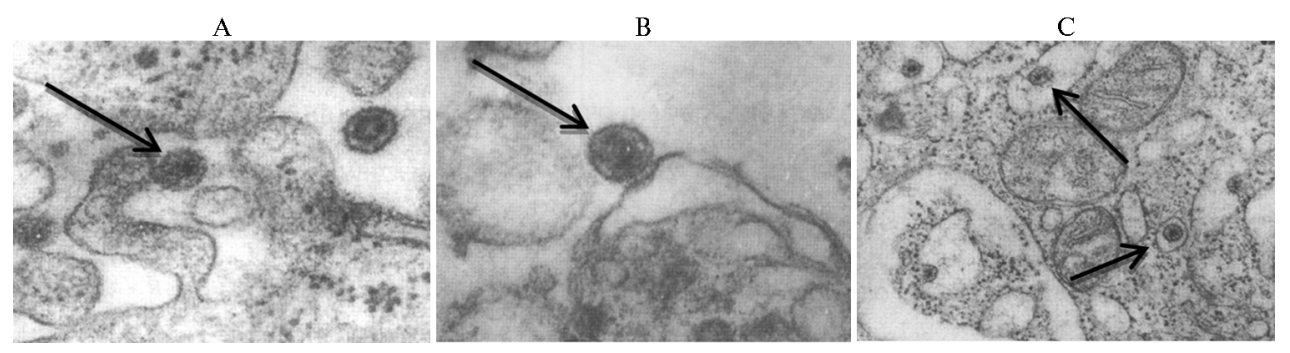

Fig. 2. Early stages of Rift Valley fever virus strain 1974-VNIIVViM interaction with sensitive cells $\left(60-90 \mathrm{~min}\right.$ at $\left.4{ }^{\circ} \mathrm{C}\right)$ : A - close contact of virion with cell $(\times 80000)$, B - plasma membrane thickening and invagination in the area of contact with virion $(\times 80000), \mathrm{C}-$ virions in intracellular vacuoles $(\times 40000)$ (marked by arrows). JEM-100S Electron Microscope (Jeol, Japan). Photo courtesy of M.A. Malakhova.

Electron microscopy of infected cell cultures revealed thickened invaginated cell membranes where the viral particles were in contact with cells (Fig. 2). Within 10 minutes after absorption at $37^{\circ} \mathrm{C}$ a partial fusion of cell membrane with viral envelope was observed. During the adsorption period, virus particles were also seen in intracellular vacuoles. Most sensitive cells were found to be infected at the virus adsorption.

Molecular characterization was based on the comparison and phyloge- 
netic analysis of gene nucleotide sequences and the primary structure of the major immunodominant proteins ( $\mathrm{Gn}$ and $\mathrm{Gc}$ glycoproteins and $\mathrm{N}$ nucleoprotein) in strain 1974-VNIIVViM and several virulent and vaccine RVF virus strains. We studied three extended portions of two genome segments, i.e. a complete nucleotide sequence of $\mathrm{N}$ nucleoprotein gene sized 738 bp ( $\mathrm{S}$ segment, base pairs 917 to 1654), a sequence encoding Gn glycoprotein sized 1602 bp (M segment, base pairs 485 to 2087) and a Gc glycoprotein gene sequence sized 1404 bp (M segment, base pairs 2090 to 3494).

Phylogenetic analysis demonstrated a close relation of strain 1974VNIIVViM to strains Smithburn and Entebbe (more than $90 \%$ ) allowing their grouping into a separate cluster (Fig. 3).

Based on the results of phylogenetic analysis, a decision was made to compare nucleotide and amino acid sequences of genes encoding glycoproteins Gn and Gc and nucleoprotein N in strains 1974-VNIIVViM, Smithburn and Entebbe to estimate their antigenic relatedness. Most nucleotide substitutions in strain 1974-VNIIVViM were synonymous and did not alter the primary protein structure, with insertion and deletion missing. In all three portions analyzed, strain 1974-VNIIVViM was close to strains Smithburn and Entebbe. Thus, eight substitutions were identified in the $\mathrm{N}$ gene $\mathrm{S}$ segment nucleotide sequence when compared to virulent strain Entebbe, and one substitution was found when compared to attenuated strain Smithburn. Nucleotide substitutions resulted in amino acid substitutions in the nucleoprotein $\mathrm{N}$, which were completely similar to those of strain Smithburn in relation to strain Entebbe, i.e. $\mathrm{Lys}_{43} \rightarrow \mathrm{Arg}_{43}$, $\mathrm{Lys}_{187} \rightarrow \mathrm{Arg}_{187}, \mathrm{Ser}_{207} \rightarrow \mathrm{Asn}_{207}, \mathrm{Glu}_{216} \rightarrow \mathrm{Gly}_{216}, \mathrm{Arg}_{219} \rightarrow \mathrm{Lys}_{219}$. Most of the amino acid substitutions were characteristic of other GenBank strains and isolates. Probably, they are not critical and do not affect viral replication.

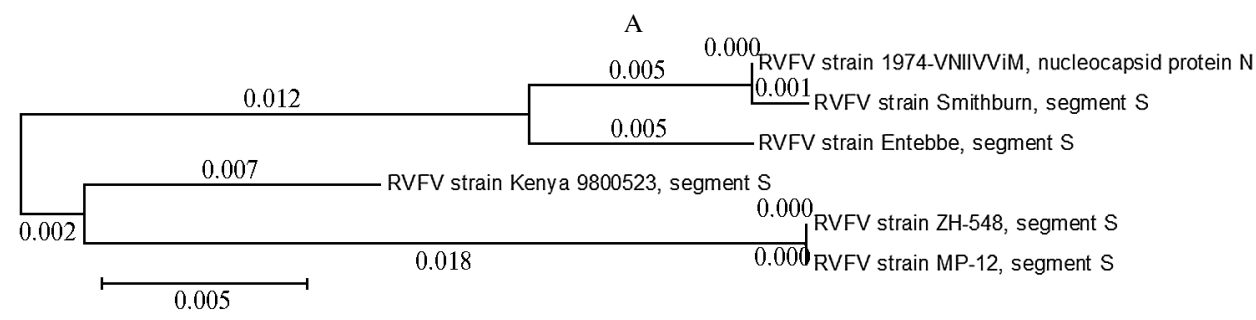

B

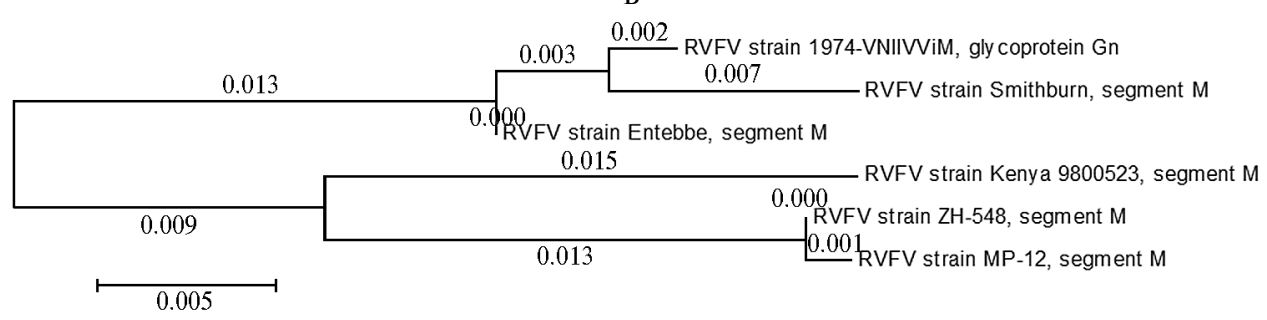

C

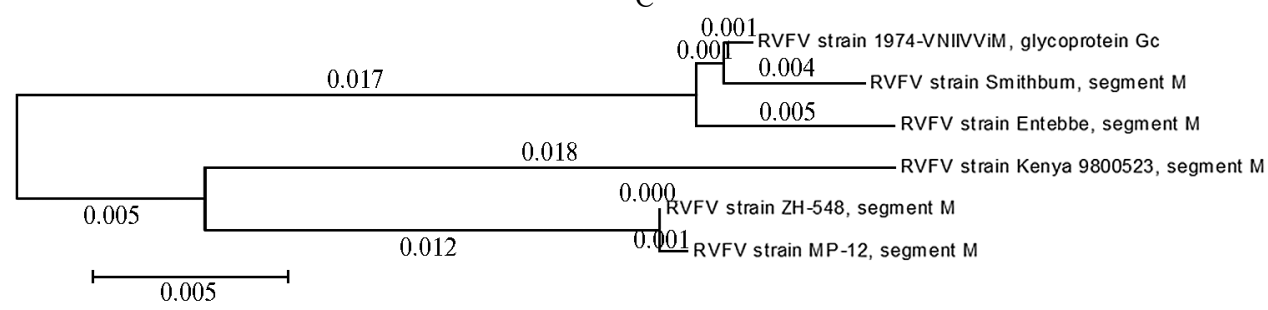

Fig. 3. Dendrograms of phylogenetic closeness of 1974-VNIIVViM and other Rift Valley fever virus isolates, as to nucleotide sequences encoding $\mathrm{N}$ nucleoprotein (A), $\mathrm{Gn}$ glycoprotein (B), and $\mathrm{Gc}$ glycoprotein (B) (method of maximum likelihood). 
In the nucleotide sequence encoding glycoprotein Gn of strain 1974VNIIVViM, we found eight substitutions relative to a similar sequence of $\mathrm{M}$ segment of a virulent strain Entebbe, and 14 substitutions when compared with $\mathrm{M}$ segment of strain Smithburn. According to the published data [31], Gn glycoprotein contains epitopes that induce the formation of virus neutralizing antibodies, thus, nucleotide substitutions may be critical for both virulence and immunogenicity. The following substitutions were found in the strain 1974-VNIIVViM Gn molecule with respect to the corresponding sequence of the precursor polypeptide encoded by the virulent strain Entebbe $M$ genome segment: ssp $_{75} \rightarrow$ Asn $_{75}$, $\mathrm{Tyr}_{120} \rightarrow \mathrm{His}_{120}, \mathrm{Lys}_{240} \rightarrow \mathrm{Asn}_{240}, \mathrm{Val}_{302} \rightarrow \mathrm{Ile}_{302}, \mathrm{Leu}_{428} \rightarrow \mathrm{Phe}_{428}, \mathrm{Ala}_{441} \rightarrow \mathrm{Val}_{441}$, $\mathrm{Val}_{462} \rightarrow \mathrm{Ile}_{462}$. It should be noted that there was a $\operatorname{Tyr}_{120}$ (polar, uncharged amino acid) $\rightarrow \mathrm{His}_{120}$ (polar, positively charged amino acid) significant replacement in one of the epitopes (VKCPPKYGLTEDCN) which induces production of virus neutralizing antibodies.

Nine substitutions were identified in the sequence which encodes the Gc merger glycoprotein, in strain 1974-VNIIVViM relatively to the same M segment portion in virulent strain Entebbe; five substitutions were found in attenuated strain Smithburn (no change in potential glycosylation sites). Comparing primary Gs structure in strains 1974-VNIIVViM, Entebbe, and Smithburn, we found a significant substitution of $\mathrm{Asp}_{412} \rightarrow \mathrm{Asn}_{412}$ (the Asn negative charge may have its effect on protein conformation and, therefore, on the virulence and immunogenicity).

So, comparative analysis identified phylogenetic and antigenic closeness between 1974-VNIIVViM and Smithburn and Entebbe strains of RVF virus. The high homology of studied genes is probably associated with the geography of the initial viral isolates (Africa, Uganda) and with similar attenuation techniques (serial passaging in murine brain). Similarity of primary amino acid sequences of immunodominant proteins in strains 1974-VNIIVViM and Smithburn makes it possible to allocate significant amino acid substitutions at attenuation and indirectly indicates similar immunogenic potential. A relatively lower strain 1974VNIIVViM virulence may be supposedly explained by the possible presence of deletions or significant mutations in nucleotide sequences that encode the nonstructural NSs and NSm proteins. A low number of amino acid substitutions in antigenic components compared to other attenuated strains was identified, therefore, the choice of strain 1974-VNIIVViM as a source of immunodominant protein genes and raw virus for the production of vaccines is well-grounded.

Thus, the continuous saiga kidney cell line and a roller method of culturing are most technologically advanced and provide raw virus production (strain 1974-VNIIVViM of Rift Valley fever virus) with high infectious $\left(8.23 \pm 0.21 \mathrm{lg} \mathrm{MLD}_{50} / \mathrm{cm}^{3}\right)$ and hemagglutinating (titer in passive hemagglutination reaction of 1:512) activity. Optimal conditions for virus culturing are the following: multiplicity of infection of $0.0-0.001 \mathrm{TCD}_{50} /$ cell; cattle serum concentration in maintenance medium of $2 \%$; $\mathrm{pH} 7.0-7.2$; 72-96 hours period. Three extended portions of two genome segments, i.e. a complete nucleotide sequence of $\mathrm{N}$ nucleoprotein gene sized 738 bp (S segment, base pairs 917 to 1654), a sequence encoding $\mathrm{Gn}$ glycoprotein sized 1602 bp (M segment, base pairs 485 to 2087) and a Gc glycoprotein gene sequence sized 1404 bp (M segment, base pairs 2090 to 3494) have been studied; and amino acid sequences of these three glycoproteins that are important for antigenic, immunogenic properties and for virus reproduction, have been compared. As a result, phylogenetic and antigenic closeness of strain 1974-VNIIVViM and strains Smithburn (attenuated) and Entebbe (virulent) was identified. The high homology of studied 
genes is probably associated with the origin of the initial viral isolates (from Africa and Uganda) and with similar attenuation techniques. Our results demonstrate that strain 1974-VNIIVViM may be used as a source of immunodominant protein genes and raw virus for vaccine production.

\section{REFERENCES}

1. B ird B.H., Githinji J.W.K., M a charia J.M., Kasiiti J.L., Murithi R.M., G a cheru S.G., Musa a J.O., Towner J.S., Reeder S.A., Oliver J.B., Stevens T.M., Erickson B.R., Morgan L.T., Khristova M.L, Hartman A.L., Com e r J.A., Rolli n P.E., Ksiazek T.G., Nichol S.T. Multiple virus lineages sharing recent common ancestry were associated with a large Rift Valley fever outbreak among livestock in Kenya during 2006-2007. J. Virol., 2008, 82(22): 11152-11166 (doi: 10.1128/JVI.01519-08).

2. Kn iz e A.V., D mit r e n k o N.V., S t ri z ha k o v A.A. Materialy Mezhdunarodnoi nauchno-prakticheskoi konferentsii «Veterinarnye i meditsinskie aspekty zooantropozoonozov» [Proc. Int. Conf. «Zoo anthropozoonoses: aspects of the veterinary and human medicine». Part 1]. Pokrov, 2003, chast' 1: 93-98.

3. The deadly dozen: 12 diseases global warming incubates. From Lyme disease to Ebola virus, the world Is getting sicker. 2008 [Elektronnyi resurs]. (http://preview.www.thedailygreen.com/environmentalnews/latest/deadly-dozen-global-warming-47100803).

4. Chevalie r V., P é p i n M., P lé e L., Lancelot R. Rift Valley fever - a threat for Europe? Euro Surveil., 2010, 15(10): pii=19506 (IT-resource) (http://www.eurosurveillance.org/ViewArticle.aspx?ArticleId=19506) (PMID: 20403309).

5. Cito F., Narcisi V., Danzetta M.L., I annetti S., Sabatino D.D., B ru no R., Carvelli A., Atzeni M., S a uro F., Calistri P. Analysis of surveillance systems in place in European Mediterranean countries for West Nile virus (WNV) and Rift Valley fever (RVF). Transboundary and Emerging Diseases, 2013, 60(2): 40-44 (doi: 10.1111/tbed.12124).

6. Shope R.E., P et e rs C.J., Davies F.G. The spread of Rift Valley fever and approaches to its control. Bulletin of the World Health Organization, 1982, 60(3): 299-304.

7. B ird B.H., K s i a ze k T.G., N i c hol S.T., M a c la ch la n N.J. Rift Valley fever virus. $J$. Am. Vet. Med. Assoc., 2009, 234(7): 883-893 (doi: 10.2460/javma.234.7.883).

8. R o s s i C.A., T u r e 11 M.J. Characterization of attenuated strains of Rift Valley fever virus. $J$. Gen. Virol., 1988, 69: 817-823 (doi: 10.1099/0022-1317-69-4-817).

9. Murakami S., Terasaki K., Ramirez S.I., Morrill J.C., Makino S. Development of a novel, single-cycle replicable Rift Valley fever vaccine. PLoS Negl. Trop. Dis., 2014, 8(3): e2746 (doi: 10.1371/journal.pntd.0002746).

10. G r a nd a d a m M. Rift Valley fever virus. In: Manual of security sensitive microbes and toxins. CRC Press, Boca Raton, Florida, SSHA, 2014: 201-209 (ISBN: 9781466553965).

11. P i t $\mathrm{m}$ a n P.R. In: Safety/immunogenicity/genetic drift of MP-12 Rift Valley fever vaccine (RVF MP12). U.S. Army Medical Research and Materiel Command Report (CTI: NCT00415051) (https://clinicaltrials.gov/show/NCT00415051).

12. Abd e l-R a him I.H., Abd e l- Haki m U., Hus s e in M. An epizootic of Rift Valley fever in Egypt in 1997. Rev. Sci. Tech., 1999, 18(3): 741-748 (PMID: 10588018).

13. S c h a ri n I. Seroprevalence of Rift Valley fever in sheep and goats in Zambezia, Mozambique and preparations for a metagenomic study of arboviruses in ticks. In: Sveriges lantbruksuniversitet. Swedish University of Agricultural Sciences, Uppsala, 2014: 181-189 [Elektronnyi resurs] (http://stud.epsilonslu.se).

14. Frank-Peterside N. Response of laboratory staff to vaccination with an inactivated Rift Valley fever vaccine - TSI-GSD 200. African Journal of Medicine and Medical Sciences, 2000, 29(2): 89-92 (PMID: 11379456).

15. Manuel A.F.V., Goncalves M.A., de Vries A.F. Adenovirus: from foe to friend. Rev. Med. Virol., 2006, 16: 167-186 (doi: 10.1002/rmv.494).

16. Holman D.H., Penn-Nicholson A., Wang D., Woraratanadharm J., Harr M.-K., Lu o M., Mahe r E.M., Holbrook M.R., D ong J.Y. A complex adenovirus-vectored vaccine against Rift Valley fever virus protects mice against lethal infection in the presence of preexisting vector immunity. Clin. Vaccine Immunol., 2009, 16(11): 1624-1632 (doi: 10.1128/CVI.00182-09).

17. Xiao Y., Zeng Y., Alexander E., Mehta S., Joshi S.B., Buchman G.W., Volki n D.B., Midd a u g h R.C., Is a c s S.N. Adsorption of recombinant poxvirus L1protein to aluminum hydroxide/ $\mathrm{CpG}$ vaccine adjuvants enhances immune responses and protection of mice from vaccinia virus challenge. Vaccine, 2013, 31(2): 319-326 (doi: 10.1016/j.vaccine.2012.11.007).

18. Soi R.K., Rurangi rwa F.R., Mc Guire T.C., Rwambo P.M., De Martini J.C., 
$\mathrm{Cr}$ aw ford T.B. Protection of sheep against Rift Valley fever virus and sheep Poxvirus with a recombinant Capripoxvirus vaccine. Clin. Vaccine Immunol., 2010, 17(12): 1842-1849 (doi: 10.1128/CVI.00220-10).

19. Lorenzo G., Martin-Folgar R., Rodriguez F., Brun A.. Priming with DNA plasmids encoding the nucleocapsid protein and glycoprotein precursors from Rift Valley fever virus accelerates the immune responses induced by an attenuated vaccine in sheep. Vaccine, 2008, 26: 5255-5262 (doi: 10.1016/j.vaccine.2008.07.042).

20. B o uloy M., Fli c k R. Reverse genetics technology for Rift Valley fever virus: current and future applications for the development of therapeutics and vaccines. Antiviral Res., 2009, 84: 101-118 (doi: 10.1016/j.antiviral.2009.08.002).

21. Spik K., Shurtleff A., McElroy A.K., Guttieri M.C., Hooper J.W., Schmaljohn C. Immunogenicity of combination DNA vaccines for Rift Valley fever virus, tick-borne encephalitis virus, Hantaan virus, and Crimean Congo hemorrhagic fever virus. Vaccine, 2006, 24: 4657-4666 (doi: 10.1016/j.vaccine.2005.08.034).

22. Lagerqvist N., Naslund J., Lundkvist A., Bouloy M., Ahlm C., Bucht G. Characterisation of immune responses and protective efficacy in mice after immunisation with Rift Valley fever virus cDNA constructs. Virol. J., 2009, 6(1): 6 (doi: 10.1186/1743-422X-6-6).

23. Pyat'desyat let bor'by s osobo opasnymi boleznyami zhivotnykh /Pod redaktsiei D.V. Kolbasova [50 years control of most dangerous animal diseases. D.V. Kolbasov (ed.).]. Vladimir, 2008: 54-55.

24. Belov A.B., Grebennikova T.V., Zaberezhnyi A.D., Butenko A.M., A 1ipe $r$ T.P. Veterinariya, 2007, 6: 53-55.

25. Sal'nikov N.G., Malogolovkin A.S., Kapustina O.V., T Sybanov S.Zh., Kolbas o v D.V. Materialy Mezhdunarodnoi konferentsii «Molekulyarnaya diagnostika» [Proc. Int. Conf. «Molecular diagnostics». V. 2]. Moscow, 2010, tom 2: 166-168.

26. Reed L.D., Muench H.A. Simple method of estimating fifty percent endpoints. Am. J. Hygiene, 1938, 27: 493-497.

27. Imatdinov I.R., Kazakova A.S., Prilepskaya E.P., Balysheva V.I. Materialy Mezhdunarodnoi nauchno-prakticheskoi konferentsii «Aktual'nye voprosy kontrolya infektsionnykh boleznei zhivotnykh» [Proc. Int. Conf. «Actual aspects of the infectious diseases control in animals»]. Pokrov, 2013: 154-160.

28. Tamura K., Nei M. Estimation of the number of nucleotide substitutions in the control region of mitochondrial DNA in humans and chimpanzees. Mol. Biol. Evol., 1993, 10: 512-526.

29. Vrenner S., Horne R.W. A negative staining method for high resolution electron microscopy of viruses. $B B A, 1959,34: 103-110$

30. Lakin G.F. Biometriya [Biolmetry]. Moscow, 1980.

31. Keegan K., Collett M.S. Use of bacterial expression cloning to define the amino acid sequences of antigenic determinants on the G2 glycoprotein of Rift Valley fever virus. J. Virol., 1986, 58(2): 263-270. 